Received 14.01.2014

Reviewed 11.02.2014

Accepted 14.02.2014

A - study design

B - data collection

C - statistical analysis

D - data interpretation

$\mathbf{E}$ - manuscript preparation

F - literature search

\section{The development of soil water resources in the common osier (Salix viminalis L.) field in a very dry and an average vegetation season}

\author{
Ewa KANECKA-GESZKE ${ }^{\text {ABCDEF }}$
}

Institute of Technology and Life Sciences in Falenty, Kujawsko-Pomorski Research Centre in Bydgoszcz, ul. Glinki 60, 85-174 Bydgoszcz, Poland; tel. +48 52 375-01-07, e-mail: e.kanecka-geszke@itp.edu.pl

For citation: Kanecka-Geszke E. 2014. The development of soil water resources in the common osier (Salix viminalis L.) field in a very dry and an average vegetation season. Journal of Water and Land Development. No. 21 p. 1117.

\begin{abstract}
The paper presents results of a study on changes of water resources under the common osier (Salix viminalis L.) crop in relation to local weather conditions.

Field studies were carried out since April till October of the years 2008 and 2010 in a productive field of energetic osier situated in north-eastern part of Bydgoszcz County. The study involved measurements of moisture in $100 \mathrm{~cm}$ soil profiles in the osier field of annual regrowth every ten days. The common osier was grown on mineral soil where atmospheric precipitation was the only water source and ground waters were unavailable for plants.

Performed studies showed that changes in water reserves in both the main root zone $(0-50 \mathrm{~cm})$ and in the whole soil profile were similar in the vegetation period of the same year. In a very dry vegetation season (2008), soil moisture remained at a level of hardly available water. In an average season (2010) soil moisture was at a level of field water capacity for plants.
\end{abstract}

Key words: biomass yield, soil water reserves, the common osier, water retention

\section{INTRODUCTION}

The common osier (Salix viminalis L.) is a plant of high water demands. This is a result of large productivity, high transpiration which may still maintain in dry periods and substantial losses for interception due to large leaf area [HALL 2003]. The availability of both rainfall and ground water may thus be a decisive factor for the growth and development of the common osier and, consequently, for the success of its cultivation [LINDERSON et al. 2007; LINDROTH, CIENCIALA 1996]. Critical water management period in willows, when water deficits may affect plant yielding, is at the break of spring and summer [BŁAŻEJ 2007], and according to SzCZUKOWSKI and BUDNY [2003] it may even prolong until the end of August i.e. to the period of maximum biomass increments. Water deficit in this period may significantly reduce yields of the common osier and the reduction could not be mitigated by later abundant precipitation. Yields could decrease by as much as 50\% [SZCZUKOWSKI, BUDNY 2003]. In regions of low atmospheric precipitation the yields of willow crops may decline when fields are established on shallow soils devoid of water sources other than rainfall itself [HALL 2003].

Atmospheric precipitation and air temperature are the factors largely affecting the amount of water reserves in soil in the onset of vegetation period and in the next stages of plant growth [SAMBORSKI 1992 after KoŹMIŃSKI, MICHALSKA 2005] while their unfavourable distribution negatively affects the development of water resources [TREDER, KONOPACKI 1999]. HALL [2003] reported that energetic plants would cause summer water deficits in soils in regions of summer atmospheric precipitation less than $550 \mathrm{~mm}$. 
Upper $50 \mathrm{~cm}$ soil layer containing the main root mass under willow crops [BERBEĆ, KOŁODZIEJ 2006; VOLK et al. 2001] is characterised by a faster dynamics of water reserves than the $100 \mathrm{~cm}$ soil profile.

The aim of this study was to determine changes of water reserves in $0-50 \mathrm{~cm}$ and $0-100 \mathrm{~cm}$ soil layer in a productive field of the common osier (Salix viminalis L.) of annual regrowths at different weather conditions.

\section{METHODS}

Field studies were carried out in a productive field of the common osier (Salix viminalis L.) used for energetic purposes. The field is situated in north-eastern part of Bydgoszcz County at the border of Kujawy and Pomorze. Apart from Wielkopolska, Kujawy is the region of the lowest precipitation and of high values of field evaporation in the country [BAK 2003; RoGUSKI et al. 1996].

Measurements were performed on mineral lessive soils [Urząd Gminy 2007] of the $4^{\text {th }}$ quality class watered exclusively from rainfalls under the crop of willow of annual regrowth. Two years differing in precipitation, namely 2008 and 2010, the fifth and seventh year of plant growing were selected for analysis. In the beginning of the study the productive field was fully mature.

In April 2008 soil excavations were made to the depth of $100 \mathrm{~cm}$ from which soil samples of undisturbed structure were taken for laboratory analyses with $100 \mathrm{~cm}^{3}$ cylinders. Groups of grain size fractions, percent of particular fractions and water desorption curves ( $\mathrm{pF}$ curves) were determined.

Water characteristics were determined in silt and silt-kaolin blocks and in high-pressure chambers [ZAWADZKI 1973]. Moisture at potential pF 3 was determined from retention curves for particular layers.

Soil moisture was measured in the vegetation period of the common osier since April till October every $8-15$ days with the frequency domain reflectometry (FDR) method using 1 metre profile probe PR2. Soil moisture was determined in the $100 \mathrm{~cm}$ profile at six depths: 10, 20, 30, 40, 60 and $100 \mathrm{~cm}$. Water reserves in 10-centimetre thick layers were calculated from equation:

where:

$$
Z=\frac{W h}{10}
$$

$Z$ - water reserve in soil layer, $\mathrm{mm}$;

$W$ - volumetric moisture, $\mathrm{cm}^{3} \cdot \mathrm{cm}^{-3} \%$;

$h$ - soil layer thickness, $\mathrm{cm}$.

and then summed up for $0-50 \mathrm{~cm}$ and $1-100 \mathrm{~cm}$ soil layer.

Points bordering particular categories of soil retention capacity were determined based on the $\mathrm{pF}$ curve [WALCZAK et al. 2002]:

- field water capacity $(P P W)$ at potential $\mathrm{pF} 2.2$;

- point corresponding to the start of plant growth limitation $(P H W R)$ at potential $\mathrm{pF} 3$;
- moisture of permanent wilting $(W T W)$ at potential $\mathrm{pF} 4.2$.

Then, the ranges of soil retention capacity were determined in view of water availability for plants [WALCZAK et al. 2002]. Calculated values included:

- reserve of total water available for plants $(W O D)$ as a difference of water reserve at $P P W$ and $W T W$,

- reserve of water easily available for plants $(W Ł D)$ determined from the difference between reserves at $P P W$ and water content at $P H W R$,

- reserve of hardly available water $(W T D)$ was determined from the difference between reserves at $P H W R$ and $W T W$.

During the study, periodical measurements of ground water table were performed in formerly installed wells of a depth of $370 \mathrm{~cm}$.

Every year after the end of vegetation period fresh weight willow biomass was determined and harvested plants were dried at $105^{\circ} \mathrm{C}$ to constant mass. Dry mass yield in $\mathrm{t} \cdot \mathrm{ha}^{-1}$ was calculated from determined fresh weight biomass, its water content, and surface area of plant harvesting.

Continuous record of meteorological conditions was provided by an automatic station localised in Myślęcinek - $16 \mathrm{~km}$ apart from the field. Rainfall characteristics of particular months and vegetation periods were performed based on classification proposed by TOMASZEWSKA [1994] and KACZOROWSKA [1962] and thermal characteristics - based on classification by LORENC [IMGW-PIB 2011].

\section{RESULTS}

Soil conditions. The upper layer $(0-50 \mathrm{~cm})$ of soil profile was built of loamy sand $(0-40 \mathrm{~cm})$ turning into sandy loam $(40-50 \mathrm{~cm})$. Percent content of clay in $0-50 \mathrm{~cm}$ layer was from 3 to $7 \%$. The layer $50-100$ $\mathrm{cm}$ consisted of light loam with a high content of clay fraction (from 13 to $17 \%$ ).

Water reserve at the field water capacity in the upper soil layer $(0-50 \mathrm{~cm})$ amounted $94.9 \mathrm{~mm}$ and in the whole profile $(0-100 \mathrm{~cm})-220.4 \mathrm{~mm}$. The reserve of total available water in $0-100 \mathrm{~cm}$ profile was $126.1 \mathrm{~mm}$ (Tab. 1) $46 \%$ of which constituted easily available water. Respective figures for $0-50 \mathrm{~cm}$ soil layer were $65.8 \mathrm{~mm}$ and $52 \%$.

Periodical measurements of ground water level did not show its presence down to the depth of 370 $\mathrm{cm}$. One may thus assume that the level of ground water is so deep that it does not exert any effect on plants. For this reason, the soils should be classified to a group of exclusively rain-fed soils.

Meteorological conditions. The sum of atmospheric precipitation in the vegetation period was $268.9 \mathrm{~mm}$ in 2008 and by $116.1 \mathrm{~mm}$ higher in 2010 (Tab. 2). Based on rainfall classification of KACZOROWSKA [1962], analysed periods when compared with long term data from 1970-2007 may be classified as very dry and average, respectively (Tab. 3). 
Table 1. Water reserve in soil layers at various values of the $\mathrm{pF}$ potential in field of the common osier (Salix viminalis L.)

\begin{tabular}{|c|c|c|c|c|c|}
\hline \multirow{2}{*}{$\begin{array}{c}\text { Soil } \\
\text { layer } \\
\mathrm{cm}\end{array}$} & \multicolumn{3}{|c|}{ Water reserve (mm) at: } & $\begin{array}{c}\text { Reserve of } \\
\text { easily avail- } \\
\text { able water } \\
\text { at pF 2.2-3.0 }\end{array}$ & $\begin{array}{c}\text { Reserve of } \\
\text { total avail- } \\
\text { able water } \\
\text { at pF 2.2-4.2 }\end{array}$ \\
\cline { 2 - 6 } & $\mathrm{pF} 2.2$ & $\mathrm{pF} \mathrm{3}$ & $\mathrm{pF} \mathrm{4.2}$ & \multicolumn{2}{c|}{$\mathrm{mm}$} \\
\hline $0-10$ & 20.2 & 12.2 & 4.8 & 8.0 & 15.4 \\
\hline $10-20$ & 18.7 & 11.5 & 5.0 & 7.2 & 13.7 \\
\hline $20-30$ & 17.9 & 11.5 & 4.4 & 6.4 & 13.5 \\
\hline $30-40$ & 17.2 & 10.6 & 5.1 & 6.6 & 12.1 \\
\hline $40-50$ & 20.9 & 15.3 & 9.8 & 5.6 & 11.1 \\
\hline $50-60$ & 24.5 & 19.9 & 14.5 & 4.6 & 10.0 \\
\hline $60-70$ & 24.8 & 20.1 & 13.8 & 4.8 & 11.0 \\
\hline $70-80$ & 25.1 & 20.2 & 13.1 & 4.9 & 12.1 \\
\hline $80-90$ & 25.4 & 20.4 & 12.3 & 5.1 & 13.1 \\
\hline $90-100$ & 25.7 & 20.5 & 11.6 & 5.2 & 14.1 \\
\hline $0-50$ & 94.9 & 61.1 & 29.1 & 33.9 & 65.8 \\
\hline $0-100$ & 220.4 & 162.1 & 94.4 & 58.4 & 126.1 \\
\hline
\end{tabular}

Source: own study.

Table 2. Atmospheric precipitation $P$ and air temperature $T$ in 2008 and 2010

\begin{tabular}{|l|c|r|r|r|r|r|}
\hline \multirow{3}{*}{ Period } & \multicolumn{3}{|c|}{$P, \mathrm{~mm}$} & \multicolumn{3}{c|}{$T,{ }^{\circ} \mathrm{C}$} \\
\cline { 2 - 7 } & 2008 & 2010 & $\begin{array}{r}1970- \\
2007\end{array}$ & 2008 & 2010 & $\begin{array}{r}1970- \\
2007\end{array}$ \\
\hline April & 36.1 & 28.4 & 30.9 & 8.5 & 8.3 & 8.3 \\
\hline May & 13.0 & 99.6 & 51.3 & 14.1 & 11.9 & 14.1 \\
\hline June & 14.4 & 17.1 & 61.8 & 18.0 & 17.4 & 17.2 \\
\hline July & 78.5 & 80.2 & 79.9 & 19.4 & 22.1 & 19.1 \\
\hline August & 38.6 & 92.8 & 56.9 & 18.3 & 18.9 & 18.6 \\
\hline September & 16.0 & 63.9 & 46.2 & 13.0 & 12.7 & 13.8 \\
\hline October & 72.3 & 3.0 & 36.7 & 9.4 & 6.3 & 9.0 \\
\hline $\begin{array}{l}\text { April - } \\
\text { October }\end{array}$ & 268.9 & 385.0 & 363.7 & 14.4 & 14.0 & 14.3 \\
\hline
\end{tabular}

Source: own study.

Table 3. Rainfall classification of months and vegetation periods of the common osier in the years 2008 and 2010

\begin{tabular}{|c|c|c|c|c|c|c|c|c|}
\hline \multirow{2}{*}{ Year } & \multicolumn{7}{|c|}{ Months } \\
\cline { 2 - 8 } & April & May & June & July & August & $\begin{array}{c}\text { Sep- } \\
\text { tember }\end{array}$ & $\begin{array}{c}\text { Octo- } \\
\text { ber }\end{array}$ & Mean \\
\hline 2008 & average & $\begin{array}{c}\text { very } \\
\text { dry }\end{array}$ & $\begin{array}{c}\text { ex- } \\
\text { tremely } \\
\text { dry }\end{array}$ & average & dry & $\begin{array}{c}\text { very } \\
\text { dry }\end{array}$ & $\begin{array}{c}\text { very } \\
\text { wet }\end{array}$ & $\begin{array}{c}\text { very } \\
\text { dry }\end{array}$ \\
\hline 2010 & average & $\begin{array}{c}\text { very } \\
\text { wet }\end{array}$ & $\begin{array}{c}\text { very } \\
\text { dry }\end{array}$ & average & $\begin{array}{c}\text { very } \\
\text { wet }\end{array}$ & wet & $\begin{array}{c}\text { ex- } \\
\text { tremely } \\
\text { dry }\end{array}$ & average \\
\hline
\end{tabular}

Source: own study.

In the vegetation period of 2008, the biggest rainfall was noted in July $(78.5 \mathrm{~mm})$ and the smallest in May $(13.0 \mathrm{~mm})$. In 2010 the biggest one was recorded in May $(99.6 \mathrm{~mm})$ and the smallest in October $(3.0$ $\mathrm{mm})$. According to the division proposed by TOMASZEWSKA [1994] June 2008 was the extremely dry month while May and September were very dry (Tab. $3)$. In the year 2010 October was extremely dry and June was the only very dry month. April and July were average months in both years. Three months (May, August and September) in 2010 showed rain- falls above the mean. Only one month (October) of such precipitation was noted in 2008 .

Thermal conditions of both years were similar. Based on thermal classification [LORENC 1994] both were classified as normal (Tab. 4) with mean air temperature of $14.4^{\circ} \mathrm{C}$ in 2008 and $14.0^{\circ} \mathrm{C}$ in 2010 (Tab. 2 ). Two months of the vegetation period deviated from the norm in 2008 , namely June $\left(18.0^{\circ} \mathrm{C}\right)$ classified as slightly warm and September $\left(13.0^{\circ} \mathrm{C}\right)$ classified as slightly cool. Four such months were recorded in 2010: cool May $\left(11.9^{\circ} \mathrm{C}\right)$, very warm July $\left(22.1^{\circ} \mathrm{C}\right)$, slightly cool September (as in 2008) and very cool October $\left(6.3^{\circ} \mathrm{C}\right)$.

Table 4. Thermal classification of months and vegetation periods of the common osier in the years 2008 and 2010

\begin{tabular}{|c|c|c|c|c|c|c|c|c|}
\hline \multirow{2}{*}{ Year } & \multicolumn{7}{|c|}{ Months } \\
\cline { 2 - 8 } & April & May & June & July & August & $\begin{array}{c}\text { Sep- } \\
\text { tember }\end{array}$ & $\begin{array}{c}\text { Octo- } \\
\text { ber }\end{array}$ & Mean \\
\hline 2008 & normal & normal & $\begin{array}{c}\text { slightly } \\
\text { warm }\end{array}$ & normal & normal & $\begin{array}{c}\text { slightly } \\
\text { cool }\end{array}$ & normal & normal \\
\hline 2010 & normal & cool & normal & $\begin{array}{c}\text { very } \\
\text { warm }\end{array}$ & normal & $\begin{array}{c}\text { slightly } \\
\text { cool }\end{array}$ & $\begin{array}{c}\text { very } \\
\text { cool }\end{array}$ & normal \\
\hline
\end{tabular}

Source: own study.

Changes in soil water reserves. Changes of reserves of the soil water were analysed at different precipitation (very dry and average vegetation period) and at different willow yielding. Yields of the common osier were $4.2 \mathrm{t}$ dry mass $\mathrm{ha}^{-1}$ in very dry year 2008 amd $6.9 \mathrm{t} \mathrm{DM} \cdot \mathrm{ha}^{-1}$ (larger by 64\%) in average year 2010. The yield obtained in 2010 falls within the range of yields $\left(5-7 \mathrm{t} \mathrm{DM} \cdot \mathrm{ha}^{-1} \cdot \mathrm{y}^{-1}\right)$ that can be obtained in commercial Polish fields on poor and periodically drying soils [STOLARSKI et al. 2013]. At the same time it is $31-60 \%$ of a yield that might be harvested on good soils with ground water at a depth of $150 \mathrm{~cm}$ [STOLARSKI et al. 2008]. Willow yields obtained by RYDAŁOWSKI [2013] in lysimetric studies $\left(13.3 \mathrm{t} \mathrm{DM} \cdot \mathrm{ha}^{-1} \cdot \mathrm{y}^{-1}\right)$ at ground water depth of $100 \mathrm{~cm}$ were more than 3 times those obtained in this study in the very dry year and almost two times larger than those obtained here in the average year.

Changes of water reserves under willow field were similar in the two years in both $0-50 \mathrm{~cm}$ and in 0-100 cm soil layers (Fig. 1, 2). Water reserves in the upper layer ranged from $50.5 \mathrm{~mm}$ to $110.5 \mathrm{~mm}$ between April and October 2008 (Fig. 1). The difference of water reserves was $37.1 \mathrm{~mm}$ in this period. Reserves of total available water varied periodically. In April and partly in May water reserves exceeded $P P W$ (94.9 $\mathrm{mm}$ ) because of intensive atmospheric precipitation in March $(52.3 \mathrm{~mm})$ and in the first half of April (35.9 mm). In the middle of April the amount of soil water was highest for the whole vegetation period $(110.5 \mathrm{~mm})$. Since the middle of April till the middle of June water reserves gradually declined to the level corresponding to PHWR. This was a consequence of three long rain-free periods (Fig. 1). 

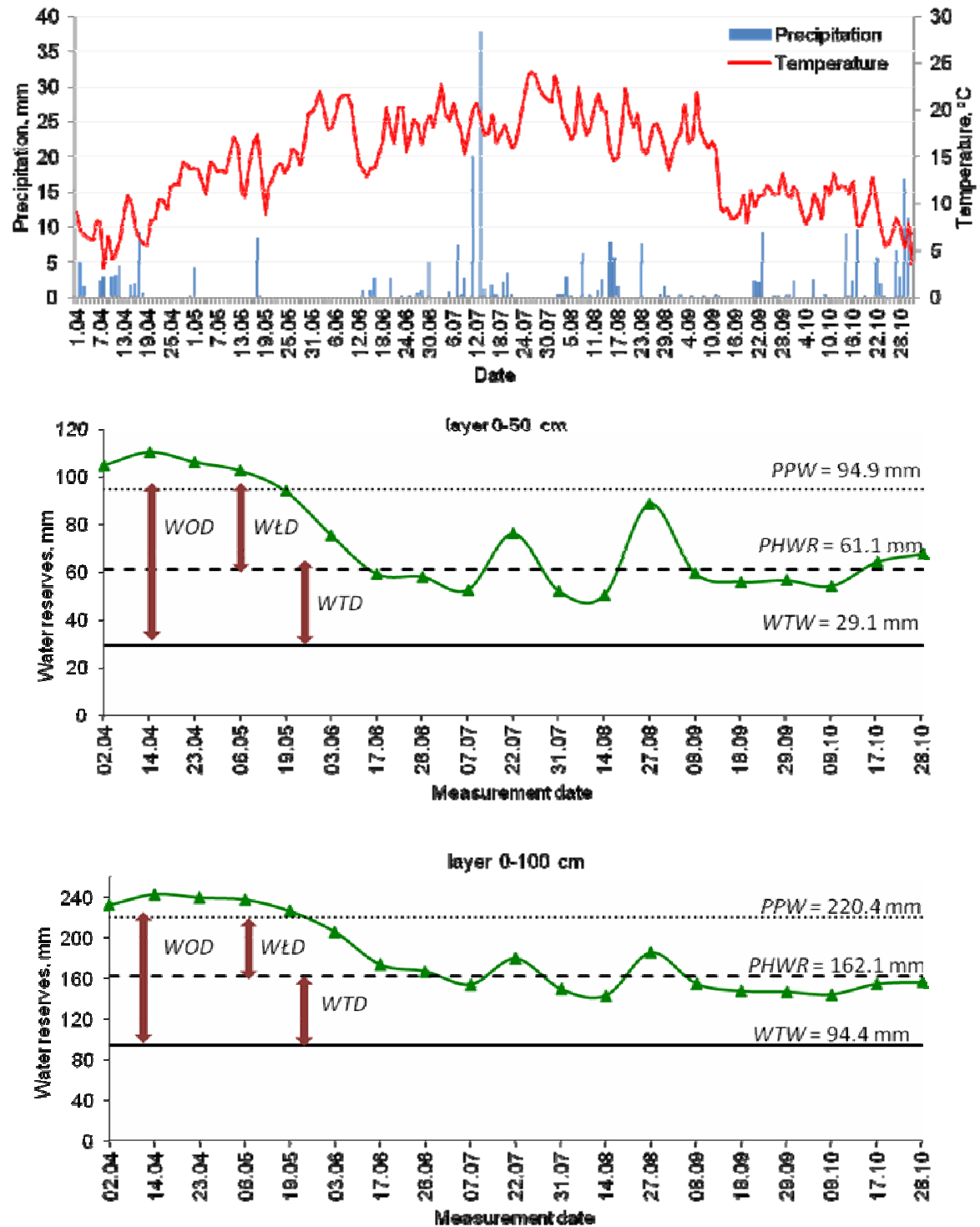

Fig. 1. Daily sums of atmospheric precipitation, mean daily air temperature and water reserves in soil (mm) in $0-50 \mathrm{~cm}$ and 0-100 cm layers under the common osier crop in 2008; WOD - total water available for plants, WŁD - water easily available for plants, $W T D$ - water hardly available for plants, $P P W$ - field water capacity, $P H W R$ - the start of plant growth limitation, $W T W$ - moisture of permanent wilting; source: own study

The first rain-free period lasting 11 days occurred at the end of April and was interrupted by a two-day precipitation $(4.5 \mathrm{~mm})$. The second rain-free period lasted till the middle of May and was also interrupted by a two-day rainfall $(8.7 \mathrm{~mm})$. The third period without precipitation was longest (25 days) and prolonged since the middle of May till the middle of June. Long rain-free periods caused the decline of soil water reserves to $52.8 \mathrm{~mm}$ i.e. to the amount of water hardly available for plants.

Since the middle of July water reserves again remained at a level of easily available for plants. Though July had average precipitations, water reserves declined in July and August because of low rainfall at the end of July, dry August and large water demands of plants. In the middle of August the smallest water reserves $(51 \mathrm{~mm})$ over the whole study period were noted. Low precipitation $(0.6 \mathrm{~mm})$ in the beginning of September made water reserves decline for the third time below $\mathrm{pF} 3$. This status remained until the middle of October. Water reserves started to increase in the beginning of October to reach 67.8 $\mathrm{mm}$ in the end of this month. A control measurement of soil moisture made in the beginning of December showed that the reserves of soil water were supplemented to the level of $P P W$ and amounted $105.6 \mathrm{~mm}$.

In the $0-100 \mathrm{~cm}$ soil layer the biggest water reserves $(243.2 \mathrm{~mm})$ were noted in April and the smallest $(143.2 \mathrm{~mm})$ in August. Since April till the middle of May water reserves were above $P P W(220.4 \mathrm{~mm})$. These reserves decreased by $78 \mathrm{~mm}$ since April till the beginning of July due to very dry May and extremely dry and slightly warm June. As in the $0-50$ $\mathrm{cm}$ layer, water reserves three times maintained within the limits of WTD for plants $(94.4-162.1 \mathrm{~mm})$. The first period when water reserves decreased below $\mathrm{pF} 3$ 

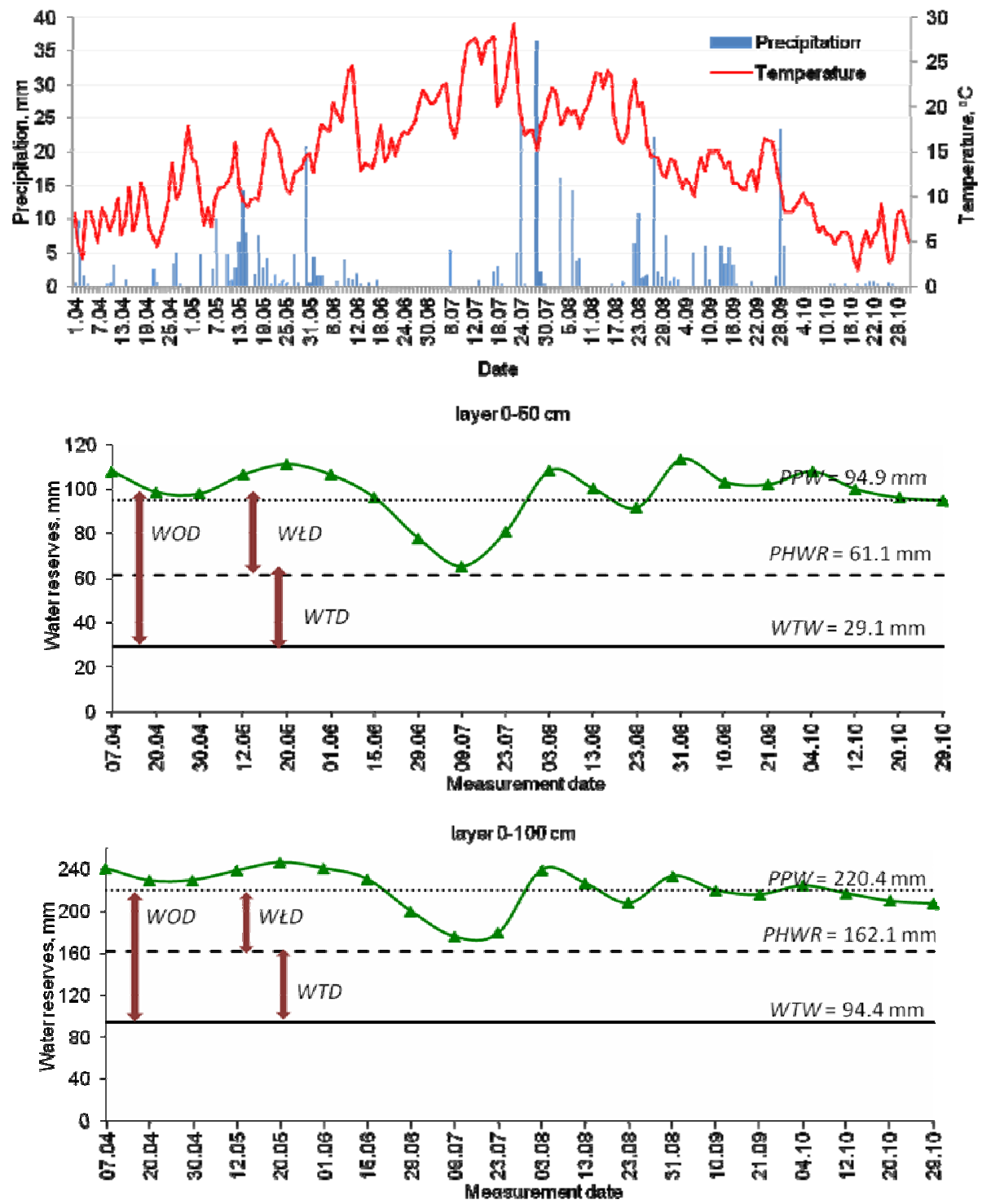

Fig. 2. Daily sums of atmospheric precipitation, daily mean air temperature and soil water reserves $(\mathrm{mm})$ in $0-50 \mathrm{~cm}$ and 0-100 cm layer under the common osier crop in 2010; explanations as in Fig. 1; source: own study

was delayed by half a month compared with water reserves in the $0-50 \mathrm{~cm}$ soil layer. Water reserves in soil profile were, however, supplemented in the same time as in the upper layer.

An increase of water reserves by $25 \mathrm{~mm}$ (within the limits of $W E D$ ) took place between 8 and 22 July after a two-week rainfall which amounted $70 \mathrm{~mm}$, in particular after two days (11 and 13 July) which in total brought $57.9 \mathrm{~mm}$ of rainfall. Several-day rain-free period at the end of July again decreased water reserves by $37 \mathrm{~mm}$ to the lowest value of $143.2 \mathrm{~mm}$ achieved in the middle of August. Dry August and very dry September made water reserves to decline below PHWR in the whole profile. Since the beginning of September till the end of October water reserves varied between 144.2 and $156.4 \mathrm{~mm}$. To the end of the study period water reserves in the $0-100$ $\mathrm{cm}$ layer were within the limits of $W T D$ for plants. Additional measurement in the beginning of December showed the supplementation of water reserves to
$205.9 \mathrm{~mm}$ but nevertheless, they did not reach the field water capacity.

The vegetation period 2008 was as a whole classified as very dry but rainfall distribution affected changes in soil water reserves. Extremely dry June, very dry May and September were decisive for classification. In May and June the reserves of easily available water were exhausted. The following short-term rainfalls limited a substantial decline of water reserves below PHWR while limitation of the decline in September could have been caused by decreased evapotranspiration at the end of willow vegetation.

For the whole vegetation period 2010 water reserves in both $0-50 \mathrm{~cm}$ and $0-100 \mathrm{~cm}$ layers maintained close to $P P W$ and within the limits of $W € D$ for plants (Fig. 2). Water reserves in 0-50 cm layer varied between 65.1 and $113.5 \mathrm{~mm}$ (Fig. 2). For most of the vegetation period of the common osier, water reserves maintained above $P P W$. 
Average April and very wet and cool May were the reasons why water reserves in $0-50 \mathrm{~cm}$ layer exceeded $P P W$ since April till the middle of June 2010. Since then, until the end of July the amount of soil water was within $W € D$. Since the beginning of April till the beginning of July water reserves decreased by $43 \mathrm{~mm}$ to reach the smallest value of the season (65.1 $\mathrm{mm}$ ) which resulted from very dry June (18 rain-free days) and low precipitation in the beginning of July $(5.4 \mathrm{~mm})$. In the summer, large increments of willow biomass were observed which translated into increased demand for water [BERBEĆ, KOŁODZIEJ 2006] and decreased soil water reserves. Precipitation recorded at the end of July $(68.7 \mathrm{~mm})$ increased water reserves above $P P W$ and such a state remained till the end of September with the exception of a short period in August. This situation was an effect of very wet August and wet September. Extremely dry October decreased water reserves at the end of this month but they still remained close to $P P W$.

Changes of water reserves in the whole soil profile were similar to those in the $0-50 \mathrm{~cm}$ layer (Fig. 2 ). In the entire season the reserves varied from 176.3 $\mathrm{mm}$ to $246.4 \mathrm{~mm}$ being close to $P P W$ and within $W O D$ and never exceeding the point of the start of plant growth limitation. In the first two and a half months (as in the upper layer) the amount of soil water was from 229.4 to $246.4 \mathrm{~mm}$ i.e. above $P P W$. Since the middle of June till August the reserves were within $W E D$. In the beginning of this period water reserves decreased by $54.3 \mathrm{~mm}$ to the lowest value of $176.3 \mathrm{~mm}$, which was caused by 18-day long rain-free period. Rainfall that occurred in July $(80.2 \mathrm{~mm})$ increased the amount of soil water. In the following weeks water reserves in the whole soil profile varied from $239.6 \mathrm{~mm}$ in August to $207.5 \mathrm{~mm}$ in October.

The analysis of soil water under the common osier crop in the first year of shoot regrowth in soil not supplied by ground water showed that water reserves in $0-50 \mathrm{~cm}$ and $0-100 \mathrm{~cm}$ layers varied largely. Under such circumstances, atmospheric precipitation was the main driver of variability in water reserves. Similar studies of RYDAŁOWSKI [2013] in conditions of stable ground water table showed that rainfall variability had no effect on mean soil moisture in the layer from ground water table to the ground surface.

\section{SUMMARY}

In productive field of the common osier on soil exclusively supplied by rainfalls the difference of soil water reserves in 0-50 cm layer was $37.1 \mathrm{~mm}$ in very dry vegetation season 2008 and $13.3 \mathrm{~mm}$ in the average season of 2010. Respective differences in the whole soil profile were $76.1 \mathrm{~mm}$ and $33.4 \mathrm{~mm}$. So, the difference was three times bigger in dry than in average season in $0-50 \mathrm{~cm}$ soil layer and over two times bigger when the whole soil profiles were compared. Seasonal changes in water reserves under wil- low crop were similar in the main root zone $(0-50$ $\mathrm{cm})$ and in the whole soil profile $(0-100 \mathrm{~cm})$.

In the average vegetation period of 2010 water reserves were within the limits of easily available water and for most of the season - at a level of field water capacity. In the very dry vegetation period of 2008 , water reserves maintained at the border of easily and hardly available water often decreasing below the point of the beginning of plant growth limitation. This could contribute to obtaining smaller yield compared with that in the year of average precipitation.

\section{REFERENCES}

BĄK B. 2004. Warunki klimatyczne Wielkopolski i Kujaw [Climatic conditions in Wielkopolska and Kujawy]. Woda-Środowisko-Obszary Wiejskie. T. 3. Z. specj. (9) p. 14-38.

BERBEĆ S., KoŁodziej B. 2006. Rośliny przemysłowe, specjalne i zielarskie. W: Nawadnianie roślin [Industrial, special and herbal plants. In: Watering of plants]. Eds S. Karczmarczyk, L. Nowak. Poznań. PWRiL p. 421-444.

BŁAŻEJ J. 2007. Nieinfekcyjne i infekcyjne czynniki chorobotwórcze krzaczastej formy wierzby (Salix viminalis L.) uprawianej na plantacjach towarowych w województwie podkarpackim [Non-infectious and infectious disease factors of a shrub form of willow (Salix viminalis L.) grown in productive fields in Podkarpackie Province]. Postępy w Ochronie Roślin. Vol. 47. Iss. 4 p. 321-329.

Dubas J.W., TOMczyK A. 2005. Zakładanie, pielęgnacja i ochrona plantacji wierzb energetycznych [Set up, nursing and protection of energetic willows]. Warszawa. Wydaw. SGGW. ISBN 8372446172 pp. 105.

HALL R.L. 2003. Short rotation coppice for energy production, hydrological guidelines [online]. [Access 14.01.2014]. Available at: http://nora.nerc.ac.uk/2631/1/ HallShortRotationReport.pdf

IMGW-PIB 2011. Biuletyn Państwowej Służby Hydrologiczno-Meteorologicznej. Warszawa. ISSN 1730-6124.

KaCZOROwSKa Z. 1962. Opady w Polsce w przekroju wieloletnim [Precipitation in Poland in a long run]. Prace Geograficzne Inst. Geogr. PAN. Nr 33 pp. 109.

KoŹMIŃSKI CZ., MichaLSKA B. 2005. Zmienność czynników meteorologicznych kształtujących pozimowe zapasy wody w glebie lekkiej w Polsce [Variability of meteorological factors affecting post-winter water reserves in light soils in Poland]. Woda-Środowisko-Obszary Wiejskie. T. 5. Z. 2(15) p. 67-92.

LINDERSON M.L., IRITZ Z., LINDROTH A. 2007. The effect of water availability on stand-level productivity, transpiration, water use efficiency and radiation use efficiency of field-grown willow clones. Biomass and Bioenergy. Vol. 31 p. $460-468$.

Lindroth A., Cienciala E. 1996. Water use efficiency of short-rotation Salix viminalis at leaf, tree and stand scales. Tree Physiology. Vol. 16 p. 257-262.

ROGUSKI W., KASPERSKA W., ŁABĘDZKI L. 1996. Warunki termiczne i opadowe w Bydgoszczy w latach 19451994 na tle lat 1848-1930 [Thermal and precipitation conditions in Bydgoszcz in the years 1945-1994 compared with the years 1848-1930]. Wiadomości IMUZ. T. 19. Z. 1 s. 7-20. 
RYDAŁOWSKI M. 2013. Wpływ poziomu wody gruntowej i wilgotności gleby piaszczystej na roczne przyrosty biomasy wierzby wiciowej w świetle badań lizymetrycznych [The effect of ground water level and moisture of sandy soil on annual biomass increments of the common osier in view of lysimetric studies]. Woda-Środowisko-Obszary Wiejskie. T. 13. Z. 4 (44) p. 115-128.

SAMBORSKI A. 1992. Wpływ elementów meteorologicznych i pokrywy roślinnej na zmiany zapasu wody w profilu glebowym [The effect of meteorological factors and plant cover on changes of water reserve in soil profile]. Annales UMCS. Vol. 11. Iss. 7. Sect. E 19.

Stolarski M., SzczUKOWSKi S., TwOrKowski J., Klasa A. 2008. Productivity of seven clones of willow coppice in annual and quadrennial cutting cycles. Biomass and Bioenergy. Vol. 32 p. 1227-1234.

SZCZUKOWSKI S., BUDNY J. 2003. Wierzba krzewiasta - roślina energetyczna [Shrub willow - an energetic plant]. Olsztyn. WFOSiGW. ISBN 9788391522417 pp. 56.

TOMASZEWSKA T. 1994. Susze atmosferyczne na przestrzeni ostatniego czterdziestolecia [Atmospheric droughts in the last four decades]. 25 Zjazd Agrometeorologów. Olsztyn-Mierki 27-29 września 1994. Materiały konferencyjne. Olsztyn. Wydaw. ART p. 169-178.

TREDER W., KONOPACKI P. 1999. Impact of quantity and intensity of rainfall on soil water content in an orchard located in the central part of Poland. Journal of Water and Land Development. No. 3 p. 47-58.
Urząd Gminy 2007. Projekt założeń do planu zaopatrzenia gminy Dobrcz w ciepło, energię elektryczną i paliwa gazowe [Assumptions to the plan of supplying Dobrcz commune in heat, electric energy and gaseous fuels]. Dobrcz.

VolK T.A., ABrahamson L.P., White E.H. 2001. Biomass power for rural development. Technical report: Root dynamics in willow biomass crops [online]. Interim Report Prepared for the United States Department of Energy under Cooperative Agreement No. DE-FC3696GO 10132. Syracuse, NY. [Access 14.01.2014]. Available at: http://www.esf.edu/willow/pdf/reports/ 2001\%20 RootsReport.pdf

WALCZAK R., OSTROWSKI J., WitKOWSKA-WALCZAK B., SŁAWIŃSKI C. 2003. Hydrofizyczne charakterystyki mineralnych gleb ornych Polski [Hydro-physical characteristics of mineral arable soils of Poland]. Acta Agrophysica. Vol. 79 p. 1-64 + 33 maps.

ZAWADZKI S. 1973. Laboratoryjne oznaczanie zdolności retencyjnych utworów glebowych [Laboratory determination of retention capacities of soil formations]. Wiadomości IMUZ. T. 11. Z. 2 p. 11-31.

StOlARSKI M., SZCZUKOWSKI S., TwORKOWSKI J., KRZYŻANIAK M. Lignocellulosic biomass production and delivery for biorefineries [online]. [Access 14.01.2014]. Available at: https://www.landbrugsinfo.dk/Planteavl/ Plantekongres/Sider/pl plk 2012 resume L41_Mariusz_Stolarski_UK.pdf?download=true

\section{Ewa KANECKA-GESZKE}

Kształtowanie się zapasów wody w glebie na plantacji wierzby wiciowej (Salix viminalis L.) w bardzo suchym i przeciętnym okresie wegetacji

\section{STRESZCZENIE}

\section{Słowa kluczowe: plon biomasy, retencja wodna, wierzba wiciowa, zapasy wody w glebie}

W pracy przedstawiono analizę wyników badań dotyczących przebiegu zmian zapasów wody w glebie pod uprawą wierzby wiciowej (Salix viminalis L.) na tle warunków meteorologicznych panujących w okolicy.

Badania polowe prowadzono na plantacji produkcyjnej wierzby wiciowej przeznaczonej do celów energetycznych zlokalizowanej w północno-wschodniej części powiatu bydgoskiego. Badania terenowe wykonywano w latach 2008 i 2010, w okresie od kwietnia do października. Prace badawcze obejmowały około dekadowy pomiar wilgotności objętościowej w 100-centymetrowym profilu gleby na plantacji wierzby o odrostach rocznych. Wierzbę uprawiano na glebie mineralnej o gospodarce wodnej opadowo-retencyjnej, w której jedynym źródłem wody są opady atmosferyczne, a wody gruntowe są niedostępne dla roślin.

Zmiany zapasów wody zarówno w głównej warstwie korzeniowej $(0-50 \mathrm{~cm})$, jak i w całym profilu glebowym $(0-100 \mathrm{~cm})$ pod uprawą wierzby miały podobny przebieg w ciagu okresu wegetacji tej rośliny w danym roku. W okresie wegetacyjnym bardzo suchym (2008) wilgotność gleby utrzymywała się na granicy wody trudno dostępnej. W okresie wegetacyjnym przeciętnym (2010) wilgotność utrzymywała się na granicy polowej pojemności dla roślin. 